\title{
Nutrient uptake by grape in a Brazilian soil affected by rock biofertilizer
}

\author{
N.P. Stamford ${ }^{1 *}$, I.P. Andrade ${ }^{2}$, S. da Silva Junior ${ }^{1}$, M.A. Lira Junior ${ }^{1}$, \\ C.E. de Rosália e Silva Santos ${ }^{1}$, A.D. Santiago de Freitas ${ }^{1}$, P. Van Straaten ${ }^{3}$ \\ ${ }^{1}$ Department of Agronomy, University Federal Rural of Pernambuco, 52171-900, Dois Irmãos, Recife Pernam- \\ buco, Brazil. ${ }^{2}$ Department of Soil Science. University Federal Rural of Amazonas, Paragominas, Amazonas, \\ Brazil. ${ }^{3}$ University of Guelph, School of Environmental Sciences, Guelph, Ontario, Canada. *Corresponding \\ author: newtonps@depa.ufrpe.br
}

\begin{abstract}
PK rock biofertilizers made from rocks and elemental sulphur inoculated with Acidithiobacillus improve yield of many short cycle plants similarly to soluble fertilizers. This study aims to evaluate the potential of PK rock biofertilizers for grape cultivation in the Brazilian San Francisco Valley. Three sources of P and K were compared: (a) soluble fertilizers, (b) biofertilizers plus elemental sulphur inoculated with Acidithiobacillus, and (c) ground phosphate and potash rocks, all at three application rates. A control treatment without $\mathrm{P}$ and $\mathrm{K}$ fertilization was added. Earthworm compound was applied as $\mathrm{N}$ source in all treatments. Grape (Vitis vinifera $\mathrm{cv}$. Italia Pirovano) was cultivated in a dystrophic Planossol (medium texture) at the San Francisco River in the Brazilian Semiarid. P, K, Ca, Mg, $\mathrm{S}_{-} \mathrm{SO}_{4}{ }^{2-}$ and Fe concentrations were analyzed in grape leaves and fruits. The results showed adequate leaf contents of $\mathrm{S}_{-} \mathrm{SO}_{4}{ }_{4}^{2-}, \mathrm{K}$, and Fe with $\mathrm{PK}$ biofertilizer application plus earthworm compound, which indicates this may be alternative to soluble fertilizer for grape in soils with low available $\mathrm{P}$ and $\mathrm{K}$.
\end{abstract}

Keywords: Acidithiobacillus, Vitis vinifera, mineral solubility, nutrients absorption, sulphur oxidative bacteria. 


\section{Introduction}

Grape (Vitis vinicola L.) is a major crop in several European countries, the United States, Australia, Chile, Argentina and Brazil. In Brazil, it is traditionally found in the uplands of the sub-tropical Rio Grande do Sul state. More recently, though, it is extending to the tropical semiarid San Francisco River valley, Northeastern Brazil, where two grape harvests per year are possible, when adequately irrigated. Viticulture is always intensively managed, with high agrochemical inputs, including fertilizers (Leão, 2003). Since fertilization represents up to $30 \%$ of the production costs in grape agricultural systems (Christensen and Kearney, 2000), it should be continually researched to increase its efficiency, while reducing the cost.

A possibility for this cost reduction is using slowrelease rock and mineral fertilizers, such as phosphate rocks, biotite and other K-rich volcanic rocks as well as "green rock fertilizers" like ground basalt. These rocks and minerals need to be processed by physical, chemical or biological means to enhance nutrient availability (van Straaten, 2007). Acidithiobacillus is a soil bacterium which is not very abundant in agricultural soils, but is highly efficient in elemental sulphur oxidation to sulfuric acid which can increase nutrient availability from both phosphate and potassium bearing rocks (Stamford et al., 2009).

Rock biofertilizers from $\mathrm{P}$ and $\mathrm{K}$ rocks plus sulphur inoculated with Acidithiobacillus have been applied with excellent results in different crops and soils of the rain forest zone and in the semiarid region of the Brazilian Northeast, as reported by Stamford et al., (2006, 2007, 2009), but no literature was found on biofertilizer usage on grapes, or on long-term field cultures.

The study aims to evaluate the effects of PK rock biofertilizers under field conditions on the nutritional status (leaves and fruits) of grapes cultivated in the San Francisco Valley of the Brazilian semiarid region.

\section{Material and Methods}

\subsection{Biofertilizer production}

The Biofertilizers were produced with "Gafsa" natural phosphate, containing $13.6 \%$ of total $\mathrm{P}$; and with potassium bearing rock (biotite) from Santa Luzia, Paraiba, Brazil, containing 9\% of total K. The data for $P$ and $K$ powdered rocks, $P$ and $K$ biofertilizer mixed with organic matter $(\mathrm{OM})$ are presented in Table 1. 
Table 1. Available $\mathrm{P}$ and $\mathrm{K}$, and $\mathrm{pH}$ of the mixture biofertilizers plus organic matter (earthworm compound) and PK bearing rock minerals (natural phosphate and biotite).

\begin{tabular}{|c|c|c|c|c|}
\hline \multirow[t]{2}{*}{ Chemical element } & $\begin{array}{c}\text { P Biofertilizer + } \\
\text { OM }\end{array}$ & Phosphate & $\begin{array}{c}\text { K Biofertilizer }+ \\
\text { OM }\end{array}$ & Biotite \\
\hline & \multicolumn{4}{|c|}{ - } \\
\hline Total $\mathrm{N}$ & 1.21 & 0.00 & 1.20 & 0.00 \\
\hline Total $\mathrm{P}_{2} \mathrm{O}_{5}$ & 27.48 & 28.98 & 1.99 & 1.21 \\
\hline Available P* & 5.00 & 6.00 & 0.09 & 0.05 \\
\hline Total $\mathrm{K}_{2} \mathrm{O}$ & 0.96 & 0.00 & 7.81 & 9.06 \\
\hline Available K & 0.04 & 0.00 & 0.09 & 0.98 \\
\hline Total $\mathrm{CaO}$ & 41.76 & 43.89 & $\mathrm{ND}^{(1)}$ & ND \\
\hline Total $\mathrm{MgO}$ & 0.40 & 0.32 & 7.33 & 8.58 \\
\hline Total $\mathrm{Fe}_{2} \mathrm{O}_{3}$ & 0.23 & 0.18 & 15.48 & 16.29 \\
\hline Total $\mathrm{MnO}$ & ND & ND & 1.50 & 0.94 \\
\hline $\mathrm{pH}-$ water $_{(1: 2.5)}$ & 5.1 & 6.4 & 5.0 & 6.1 \\
\hline
\end{tabular}

(1) $\mathrm{ND}=$ not determined;

*Available P by the Embrapa (1997) extracted by Mehlich 1.

Biofertilizers were prepared separately for $\mathrm{P}$ and $\mathrm{K}$, by mixing each rock with fine powdered elemental sulphur (200 mesh) on a 10:1 mass to mass ratio, and inoculated with Acidithiobacillus sulphur oxidative bacteria. The sulphur oxidative bacteria were cultivated in specific medium (El Tarabily et al., 2006), in $125 \mathrm{~mL}$ Erlenmeyers, at $180 \mathrm{rpm}$ and $24-25^{\circ} \mathrm{C}$, for 5 days. Acidithiobacillus was applied at $10^{7}$ viable cells $\mathrm{mL}^{-1}$ through inoculation of a 1:10 (v:v) mixture with distilled water, which was pulverized to $20 \mathrm{~cm}$ deep layers of the rock: sulphur mixture. The mix was kept near field capacity for 60 days, after which $\mathrm{pH}$ in water, available $\mathrm{P}$ and $\mathrm{K}$ were determined following Embrapa (1997) with the following results: BP- $\mathrm{pH}$ 3.3; available P $50\left(\mathrm{~g} \mathrm{~kg}^{-1}\right)$ and $\mathrm{BK}-\mathrm{pH} 3.0$; available $\mathrm{K} 10\left(\mathrm{~g} \mathrm{~kg}^{-1}\right)$.
The $\mathrm{P}$ and $\mathrm{K}$ biofertilizer were mixed 1:4 (m:m) with earthworm compound (OM), to neutralize their excessive acidity, with final $\mathrm{pH} 6.1$ and 6.0 , respectively (Table 1).

\subsection{Soil and experimental conditions}

The field experiment was conducted at a production farm (08 $59^{\prime} 49^{\prime \prime} \mathrm{S}, 40^{\circ} 16^{\prime} 19^{\prime}$ ' W and altitude $300 \mathrm{~m}$ ) of the Botticelli Company, located at the San Francisco Valley, Pernambuco state, semiarid region of the Brazilian Northeastern. The climate is classified as "BSwh" according to the Köppen classification.

The soil used was a Dystrophic Planossol medium texture (Embrapa, 1999) representative of the region, with low available $\mathrm{P}$ and $\mathrm{K}$, predominantly used for 
grape and mango. Soil chemical and physical properties were analyzed in soil samples collected before the experiment. The soil was analyzed using Embrapa (1997) methodology with the following results: $\mathrm{pH}$ $\left(\mathrm{H}_{2} \mathrm{O} 1.0: 2.5\right)=5.8$; available $\mathrm{P}=15 \mathrm{mg} \mathrm{dm}^{-3}$; soluble $\mathrm{S}_{-\mathrm{SO}_{4}^{-2}}^{-2} 26 \mathrm{mg} \mathrm{dm}{ }^{-3}$; exchangeable cations $\left(\mathrm{cmol}_{\mathrm{c}}\right.$ $\left.\mathrm{dm}^{-3}\right): \mathrm{Ca}^{2+}=1.88 ; \mathrm{Mg}^{2+}=0.37 ; \mathrm{K}^{+}=0.18$; micronutrients $\left(\mathrm{mg} \mathrm{dm}^{-3}\right): \mathrm{B}=10.8 ; \mathrm{Zn}=4.8 ; \mathrm{Cu}=6.6 ; \mathrm{Mn}$ $=5.2 ;$ total $\mathrm{N}=0.7 \mathrm{~g} \mathrm{~kg}^{-1}$ and organic matter $=19.5$ $\mathrm{g} \mathrm{kg}^{-1}$; global density $\left(\mathrm{g} \mathrm{cm}^{-3}\right) 1.67$; bulk density $(\mathrm{g}$ $\left.\mathrm{cm}^{-3}\right) 2.63$; texture $\left(\mathrm{g} \mathrm{kg}^{-1}\right)$ sand $=650$; silt $=169$ and clay $=181$.

The table grape cultivar "Italia Pirovano" was used due to its high commercial and agricultural value in the region (Leão, 2003). Grape seedlings at 90 days were transplanted to furrows $(40 \times 40 \times 40 \mathrm{~cm})$ in 210 $\mathrm{m}^{2}$ plots (35.0 $\mathrm{m}$ long and $6.0 \mathrm{~m}$ wide), with two rows, spaced at $3.5 \times 3.0 \mathrm{~m}$ for 20 plants per plot and a total of 1404 plants in the experiment (1.228 ha).

All plants received, at seedling transplantation, the same basic fertilization following the IPA (2008) recommendations and $2 \mathrm{~L}_{\text {plant }}{ }^{-1}$ of cow manure as producers practice. The fertilizers were applied $20 \mathrm{~cm}$ deep and $20 \mathrm{~cm}$ distant from plant base.

Soil water was maintained near field capacity using computer controlled micro irrigation. All grape cultural practices, including pesticide application, were accompanied weekly after pruning, by Embrapa (Brazilian Agricultural Research Company), as required by Fruit Integrated Program (FIP) fresh fruit export guidelines. Grapes were pruned to two shoots, each with eight to ten gens, two months before each harvest and shoots were wrapped on the fruiting wires.

\subsection{Experimental design and data collection}

The experiment was a factorial arrangement with fertilizer sources (soluble fertilizer; biofertilizer; powdered rock) and rates (50, 100 and $150 \%$ of Pernambuco state grape fertilization recommendation, IPA (2008), and was conducted in a randomized block design, with four replicates. Fertilization was after each pruning (12 and 18 months after seedling transplantation - AST), using the same procedure described for basic fertilization. Fertilizers sources and rates $(\mathrm{P}+\mathrm{K})$ were: (a) soluble $\mathrm{P}$ fertilizer (single superphosphate $=$ 300,450 and $600 \mathrm{~kg} \mathrm{ha}^{-1}$ ) + soluble $\mathrm{K}$ fertilizer (potassium sulphate $=70,140$ and $210 \mathrm{~kg} \mathrm{ha}^{-1}$ ); (b) biofertilizer from phosphate rock $(\mathrm{BP}=300,450$ and $600 \mathrm{~kg}$ $\left.\mathrm{ha}^{-1}\right)+$ biofertilizer from potash rock $(\mathrm{BK}=70,140$ and $\left.210 \mathrm{~kg} \mathrm{ha}^{-1}\right)$; (c) powdered rock phosphate $(\mathrm{PR}=$ 1,$000 ; 1,500$ and $\left.2,000 \mathrm{~kg} \mathrm{ha}^{-1}\right)+$ biotite bearing rock $\left(\mathrm{BR}=1,000 ; 1,500\right.$ and $\left.2,000 \mathrm{~kg} \mathrm{ha}^{-1}\right)$.

A control treatment with earthworm compound (1 L plant $\left.{ }^{-1}\right)$ and without $\mathrm{P}$ and $\mathrm{K}$ fertilization $\left(\mathrm{P}_{0} \mathrm{~K}_{0}\right)$ was used for comparative purpose. The earthworm compound was commercially available in the regional market with: $\mathrm{pH}\left(\mathrm{H}_{2} \mathrm{O}\right) 7.9$; total $\mathrm{N} 5.0\left(\mathrm{~g} \mathrm{~kg}^{-1}\right)$; available P $2.0\left(\mathrm{mg} \mathrm{kg}^{-1}\right)$ and available $\mathrm{K} 5.0\left(\mathrm{mg} \mathrm{kg}^{-1}\right)$.

Harvest was 26 month after transplant and berry composition was measured at harvest 32-berry samples per plot. Fruits were macerated and the juice was analyzed for $\mathrm{pH}$, soluble $\mathrm{SO}_{4}^{-2}$ and total $\mathrm{P}, \mathrm{K}, \mathrm{Ca}, \mathrm{Mg}$ and Fe content according to Malavolta et al., (1987). Leaves were sampled at the same time, dried, ground and analyzed for $\mathrm{P}, \mathrm{K}, \mathrm{Ca}, \mathrm{Mg}, \mathrm{S}-\mathrm{SO}_{4}{ }^{2-}$ by the same methodology. 


\subsection{Statistical analysis}

Data was analyzed by ANOVA, with significant effects evaluated by Tukey test $(p=0.01)$ using SAS. The regression equation and $\mathrm{R}^{2}$ values between biofertilizer treatments (sources and rates) and concentration of nutrients on grape juice were calculated.

\section{Results and Discussion}

Plants which did not receive any PK fertilizer did not produce at 26 months, due to the low natural fertility, and high plant requirements. There was a significant source $\mathrm{x}$ rate interaction for berry nutrient content and $\mathrm{pH}$ (Table 2), with higher $\mathrm{P}$ and $\mathrm{K}$ content for soluble fertilizer, while PK rocks did not show any increment with increasing fertilizer rates. At the same time, PK biofertilizer presented the higher $\mathrm{S}_{-} \mathrm{SO}_{4}, \mathrm{Mg}$ and $\mathrm{Fe}$ contents, likely due to the sulfuric acid made during biofertilizer production. This effect would be direct for $\mathrm{S}_{-} \mathrm{SO}_{4}$, and through the acid effects on biotite structure for $\mathrm{Fe}$ and $\mathrm{Mg}$. The higher Fe contents for biofertilizer than for soluble fertilizer confirm earlier observations by Christensen and Kearney (2000) and Faria 3., (2004), which found reduced Fe contents after high fertilization rates with soluble fertilizers.

Table 2. Chemical analyses in grape berries as affected by sources and rates of PK fertilizers (rock biofertilizers, soluble fertilizers and ground rocks).

\begin{tabular}{|c|c|c|c|c|c|c|c|}
\hline \multirow{3}{*}{$\stackrel{\text { PK }}{\text { Fertilization }}$} & \multicolumn{7}{|c|}{ Chemical analyses in grape berries } \\
\hline & $\mathrm{pH}\left(\mathrm{H}_{2} \mathrm{O}\right)$ & $\mathbf{P}$ & $\mathrm{S}_{4} \mathrm{SO}_{4}^{-2}$ & $\mathbf{K}$ & $\mathbf{C a}$ & Mg & $\mathrm{Fe}$ \\
\hline & \multicolumn{7}{|c|}{ 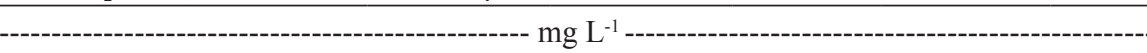 } \\
\hline Biofertilizer $_{50}$ & $3.2 \mathrm{Bb}$ & $25 \mathrm{Cb}$ & $27 \mathrm{Ba}$ & $902 \mathrm{Bb}$ & $64 \mathrm{Cb}$ & $94 \mathrm{Ba}$ & $9 \mathrm{Ca}$ \\
\hline Biofertilizer ${ }_{100}$ & $3.3 \mathrm{ABb}$ & $33 \mathrm{Bb}$ & $36 \mathrm{Aa}$ & $1003 \mathrm{Ab}$ & $74 \mathrm{Bb}$ & $102 \mathrm{Aa}$ & $13 \mathrm{Ba}$ \\
\hline Biofertilizer $_{150}$ & $3.4 \mathrm{Ab}$ & $40 \mathrm{Ab}$ & $40 \mathrm{Aa}$ & $1040 \mathrm{Ab}$ & $87 \mathrm{Ab}$ & $113 \mathrm{Aa}$ & $14 \mathrm{Aa}$ \\
\hline Fertilizer $_{50}$ & $4.0 \mathrm{Ca}$ & $38 \mathrm{Ca}$ & $15 \mathrm{Bb}$ & $1092 \mathrm{Ca}$ & $46 \mathrm{Bc}$ & $29 \mathrm{Bc}$ & $3 \mathrm{Ac}$ \\
\hline Fertilizer ${ }_{100}$ & $4.3 \mathrm{Ba}$ & 47Ba & $19 \mathrm{ABb}$ & $1631 \mathrm{Ba}$ & $60 \mathrm{Ac}$ & $36 \mathrm{Bc}$ & $3 \mathrm{Ac}$ \\
\hline Fertilizer ${ }_{150}$ & 4.6Aa & $53 \mathrm{Aa}$ & $23 \mathrm{Ab}$ & 1996Aa & $68 \mathrm{Ac}$ & $54 \mathrm{Ac}$ & $3 \mathrm{Ac}$ \\
\hline Rocks $_{500}$ & $2.9 \mathrm{Bc}$ & $15 \mathrm{Ac}$ & $7 \mathrm{Bc}$ & $656 \mathrm{Bc}$ & $96 \mathrm{Ca}$ & $42 \mathrm{Bb}$ & $6 \mathrm{Cb}$ \\
\hline Rocks $_{1000}$ & $3.0 \mathrm{ABc}$ & $17 \mathrm{Ac}$ & $13 \mathrm{Ab}$ & $733 \mathrm{Ac}$ & $119 \mathrm{Ba}$ & $46 \mathrm{Bb}$ & $7 \mathrm{Bb}$ \\
\hline Rocks $_{1500}$ & $3.1 \mathrm{Ac}$ & $20 \mathrm{Ac}$ & $14 \mathrm{Ac}$ & 749Ac & $132 \mathrm{Aa}$ & $56 \mathrm{Ab}$ & $9 \mathrm{Ab}$ \\
\hline $\mathrm{CV}(\%)$ & 2.99 & 10.09 & 9.23 & 3.34 & 7.13 & 5.78 & 5.43 \\
\hline
\end{tabular}

Values followed by different letters are significantly different $(\alpha=0.05)$, by Tukey test. Small letters compare means between PK sources and capital letters different application rates. The control treatment produced no fruits. 
Both biofertilizer at $150 \%$ of the recommended rate and soluble fertilizer at 100 or $150 \%$ of the recommended rate presented berry $\mathrm{P}$ content higher than the $40 \mathrm{mg} . \mathrm{dm}-3$ threshold for adequate wine production (Rizzon, 2000; Rizzon and Miele 2002a, 2004; Curvelo-Garcia, 2005). On the other hand, soluble fertilizer at both 100 and $150 \%$ of the recommended rate had high $\mathrm{K}$ berry contents, exceeding the maximum of 1000 mg.L-1, as described by Corrêa et al., (2006), Curvelo-Garcia (2005), Rizzon and Miele (2002b, 2004). Fe berry content is also important in enology, with a minimum threshold of $10 \mathrm{mg} . \mathrm{dm}-3$, In enology there is also a $10.0 \mathrm{mg} \mathrm{dm}-3$ minimum concentration of $\mathrm{Fe}$ in berries (Mira 2004, CurveloGarcia, 2005), which was only exceeded by 100 and $150 \%$ of the recommended rate applied with biofertilizer (Table 2).

Berry pH was about 3.3 for biofertilizer and 4.0 for soluble fertilizer, in which case there may by wine stability problems due to increased microbiological and physical-chemical alterations (Rizzon and Miele, 2002a; Nunes, 2003; Mira 2004; Curvelo-Garcia, 2005). Rizzon and Miele (2002b) described that $\mathrm{pH}$ increases may be caused by increased concentrations of $\mathrm{K}$ in soil.
As for the berries, there was no effect of application rate for ground rock on leaf $\mathrm{K}$ content, almost none in $\mathrm{P}$ and $\mathrm{Mg}$, and only an increase over no fertilization for $\mathrm{Fe}$ (Figure 1). While leaf $\mathrm{P}$ and $\mathrm{K}$ contents increased with application rate for both soluble and biofertilizers, the increase was much stronger for soluble fertilizer, with the reverse pattern for $\mathrm{Mg}$ leaf content, similarly to berry nutrient concentrations. These results are similar to those found for sugarcane and melon (Stamford et al., 2006, 2008). Faria et al., (2004) found leaf $\mathrm{K}$ content in the San Francisco Valley in the 2.0 to 3.5 $\mathrm{g} \mathrm{kg}^{-1}$ range, much higher than the values observed in this study, of 0.1 to $0.3 \mathrm{~g} \mathrm{~kg}^{-1}$. and much lower than the 12 to $20 \mathrm{~g} \mathrm{~kg}^{-1}$ threshold for malic acid accumulation which can lower the wine quality (Jacobs, 2002).

The regression equations for nutrients in leaves are shown in Table 3. The effect of fertilizers applied in recommended rate showed that fertilizers and biofertilizers were significant and with higher values than rocks. For $\mathrm{Mg}$ the regression showed that this nutrient is closely related with Biofertilizers probably due to the content of $\mathrm{Mg}$ in biotite rock. The higher correlation may be because $\mathrm{P}, \mathrm{K}, \mathrm{Mg}$ and $\mathrm{Fe}$ are nutrients released by acidity promoted from the metabolic reaction carried out by Acidithiobacillus bacteria. 

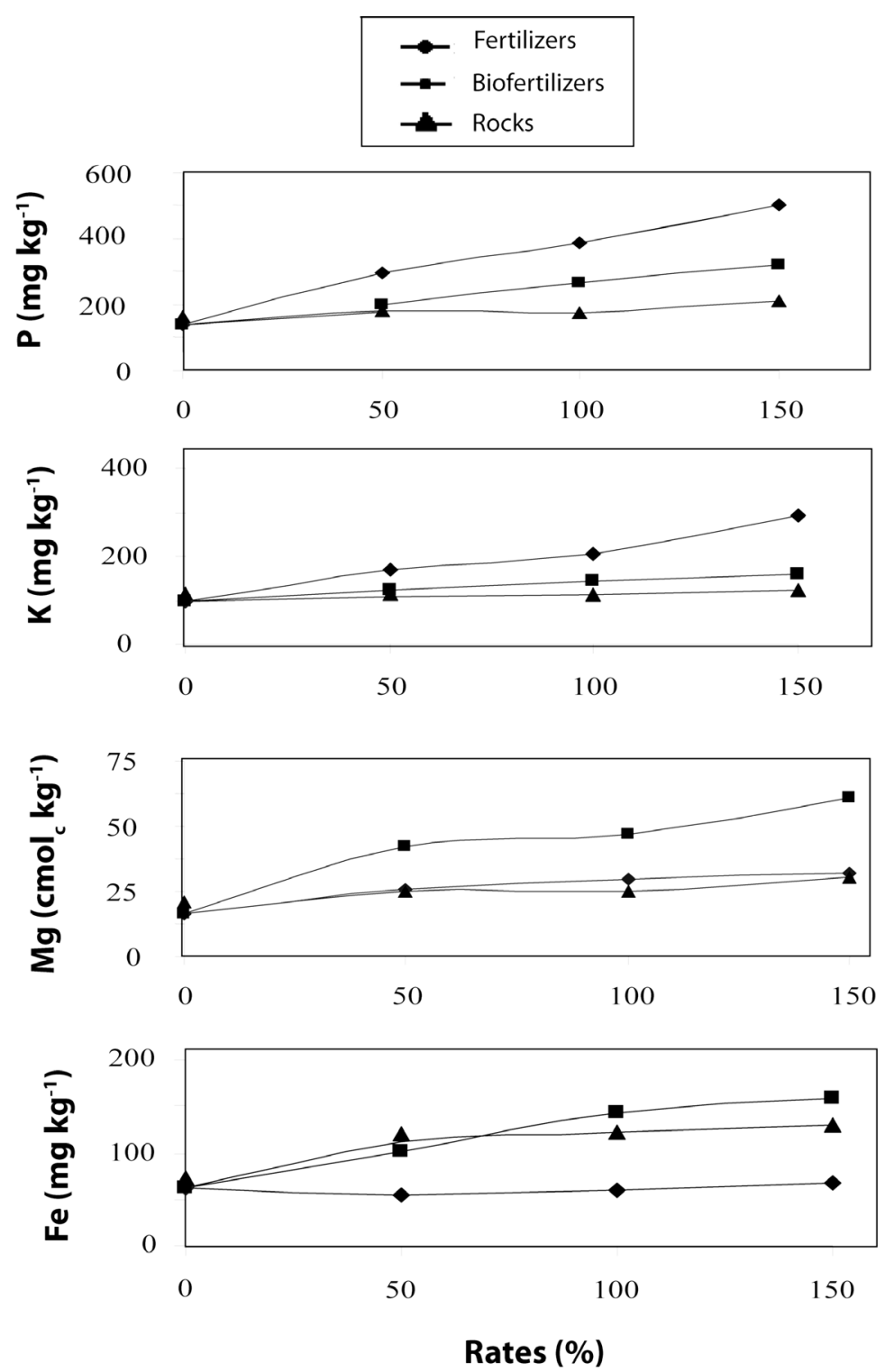

Figure 1. $\mathrm{P}, \mathrm{K}, \mathrm{Mg}$ and $\mathrm{Fe}$ in grape leaves, harvested at 26 months after seedling transplantation, as affected by sources (fertilizers, biofertilizers and rocks) and rates $\left(\mathrm{P}_{2} \mathrm{O}_{5}\right.$ and $\left.\mathrm{K}_{2} \mathrm{O}\right)$ of fertilizers treatments. 
Table 3. Regression equation and coefficient of determination, for nutrients ( $\mathrm{P}, \mathrm{S}_{-} \mathrm{SO}_{4}^{-2}, \mathrm{~K}, \mathrm{Ca}, \mathrm{Mg}$ e $\mathrm{Fe}$ ), in leaves harvested at 26 months after seedling transplantation, as affected by the fertilizers treatments (fertilizers, biofertilizers and rocks) applied in recommended rate.

\begin{tabular}{llll}
\hline Analysis in leaves & Fertilizer treatment & Regression Equation & $\mathbf{R}^{2}$ \\
\hline Total $\mathrm{P}$ & Fertilizers & $\mathrm{Y}=0.1531+0.00237 \mathrm{x}$ & $0.90^{* *}$ \\
& Biofertilizers & $\mathrm{Y}=0.1388+0.00124 \mathrm{x}$ & $0.96^{* *}$ \\
& Rocks & $\mathrm{Y}=0.1437+0.00044 \mathrm{x}$ & $0.63^{*}$ \\
Total $\mathrm{K}$ & & $\mathrm{Y}=1.3712+0.00929 \mathrm{x}$ & $0.95^{* *}$ \\
& Fertilizers & $\mathrm{Y}=0.9850+0.00582 \mathrm{x}$ & $0.97^{* *}$ \\
& Biofertilizers & $\mathrm{Y}=0.9781+0.00165 \mathrm{x}$ & $0.83^{* *}$ \\
Rocks & & \\
Total $\mathrm{Mg}$ & & $\mathrm{Y}=0.2827+0.00085 \mathrm{x}$ & $0.57^{*}$ \\
& Fertilizers & $\mathrm{Y}=0.3216+0.00499 \mathrm{x}$ & $0.92^{* *}$ \\
& Biofertilizers & $\mathrm{Y}=0.3173+0.00256 \mathrm{x}$ & $0.47^{*}$ \\
Rocks & & \\
& & $\mathrm{Y}=58.078-0.01896 \mathrm{x}$ & $0.61^{*}$ \\
& Fertilizers & $\mathrm{Y}=61.282+1.02949 \mathrm{x}$ & $0.80^{* *}$ \\
& Biofertilizers & $\mathrm{Y}=64.517+1.06272 \mathrm{x}$ & $0.85^{* *}$ \\
\hline
\end{tabular}

(1) In equation ' $\mathrm{x}$ ' correspond to recommended rate $\left(\mathrm{P}_{2} \mathrm{O}_{5}\right.$ and $\left.\mathrm{K}_{2} \mathrm{O}\right)$ for irrigated grape and ' $\mathrm{Y}$ ' variable analyzed. ** Significant $(p=001)$ and $*$ Significant $(p=005)$.

\section{Conclusions}

PK biofertilizers show potential for wine grape production, due to grape berry nutrient content usually better for wine production than observed with soluble fertilizer. This fact will be explained especially in reference to $\mathrm{P}, \mathrm{K}, \mathrm{Fe}$ and $\mathrm{SO}_{4}^{-2}$ nutrients released from the phosphate and potash rocks by the acidity promoted by the oxidative bacteria Acidithiobacillus to produce the PK biofertilizers.

\section{Acknowledgements}

The authors are indebted to $\mathrm{CNPq}$ "Conselho Nacional de Desenvolvimento Científico e Tecnológico" (National Research and Techonological Development
Council), FACEPE "Fundação de Apoio à Ciência e Tecnologia do Estado de Pernambuco (Pernambuco State Science and Technology Support Foundation) and BNB "Banco do Nordeste do Brasil S.A." (Brazilian Northeastern Bank) for the financial support and scholarships.

\section{References}

Christensen, P., Kearney, U.C. 2000. Use of Tissue Analysis in Viticulture. Cooperative Extension Work in Agriculture the University of California, $10,1-9$.

Corrêa, J.I., Waldrich, K.M., Lazzari, M.F. 2006. Vinhos. Apostila do curso de Engenharia Química e Engenharia de Alimentos. UFSC - Universidade Federal de Santa Catarina, 40p. 
Curvelo-Garcia, A.S. 2005. Práticas enológicas internacionalmente reconhecidas. Braz. J. Food Tecnol. 20, 105-130.

El-Tarabily, K.A., Soaud, A.A., Saleh, M.E., Matsumoto, S. 2006. Isolation and characterization of sulfur-bacteria, including strains of Rhizobium from calcareous soils and their effects on nutrient uptake and growth of maize (Zea mays L.). Austr. J. Agric. Res. 57, 101-111.

Empresa Brasileira de Pesquisa Agropecuária - Embrapa. 1997. Manual de métodos de análise de solo. Rio de Janeiro, Centro Nacional de Pesquisa de Solos. 212p.

Empresa Brasileira de Pesquisa Agropecuária - Embrapa. 1999. Sistema Brasileiro de Classificação dos Solos, Rio de Janeiro, Centro Nacional de Pesquisa de Solos. 426p.

Faria, C.M.B., Soares, J.M., Leão, P.C.S. 2004. Adubação verde com leguminosas em videira no submédio São Francisco. Braz. J. Soil Sci. 28, 641-648.

Garcia Júnior O. 1991. Isolation and characterization of Thiobacillus thiooxidans and Thiobacillus ferrooxidans from mineral mines. Braz. J. Microbiol. 20, 1-6.

He, Z.L., Baligar, V.C, Martens, D.C., Ritchey, K.D., Kemper, W.D. 1996. Factors affecting phosphate rock dissolution in acid soil amended with liming materials and cellulose. Soil Sci. Soc. Amer. J. 60, 1596-1601.

Instituto Agronômico de Pernambuco - IPA. 2008. Recomendações de adubação para o estado de Pernambuco. Recife, Brasil. 128p.

Jacobs, A.A. 2002. Balanced approach to vine nutrition. Cooperative Research Centre for viticulture. Viticare News. 3, 1-6.

Leão, P.C.S. 2003. Uva de mesa produção - Aspectos técnicos. Embrapa semi-árido. Petrolina, 128p.
Malavolta, E., Vitti, G.C., Oliveira, S.A. 1997. Avaliação do estado nutricional das plantas: princípios e aplicações. 2 ed. Associação Brasileira para Pesquisa da Potassa e do Fosfato, Piracicaba, São Paulo, 319p.

Mira, H. 2004. Resinas permutadoras de íons para estabilização tartárica de vinhos. Enologia. 43, 15-24.

Nunes, A. 2003. Estudo da desacidificação química em vinhos brancos da casta Fernão Pires da região do Ribatejo. Enologia. 35, 262-280.

Rizzon, L.A. 2000. Avaliação da uva cv. Isabel para a elaboração de vinho tinto. Braz. J. Food Technol. 20, 115-121.

Rizzon, L.A., Miele, A. 2002a. Acidez na vinificação em tinto das uvas Isabel, Cabernet Sauvignon e Cabernet Franc. Ciência Rural. 32, 511-515.

Rizzon, L.A., Miele, A. 2002b. Avaliação da cv. Cabernet Sauvignon para elaboração de vinho tinto. Braz. J. Food Technol. 22, 192-198.

Rizzon, L.A., Miele, A. 2004. Avaliação da cv. Tannat para elaboração de vinho tinto. Braz. J. Food Technol. 24, 91-102.

SAS Institute. 1999. SAS System for Windows. CD ROM for Windows 32 - bits.

Stamford, N.P., Moura, P.M., Lira Júnior, M.A., Santos, C.E.R.S., Duenhas, M.L., Gava, C.A.T. 2009. Chemical Attributes of an Argisoil of the San Francisco Valley after melon growth with phosphate and potash rocks biofertilizers. Braz. J. Hortic. 27, 442-447.

Stamford, N.P., Santos, C.E.R.S., Silva Junior, S., Lira Junior, M.A., Figueiredo, M.V.B. 2008. Effect of rhizobia and rock biofertilizers with Acidithiobacillus on cowpea nodulation and nutrients uptake in a tableland soil. World J. Microbiol. Biotechnol. 24, 1857-1865. 
Stamford, N.P., Santos, C.E.R.S., Dias, S.H.L. 2007. Phosphate rock biofertilizer with Acidithiobacillus and rhizobia improves nodulation and yield of cowpea (Vigna unguiculata) in greenhouse and field conditions. Trop. Grassl. 41, 222-230.
Stamford, N.P., Lima, R.A., Santos, C.E.R.S., Dias, S.H.L. 2006. Rock biofertilizers with Acidithiobacillus on sugarcane yield and nutrient uptake in a Brazilian soil. Geomicrobiol. J. 23, 261-265.

Van Straaten, P. 2007. Agrogeology - the use of rocks for crops. Enviroquest, Cambridge, Ontario, Canada, $440 \mathrm{p}$. 